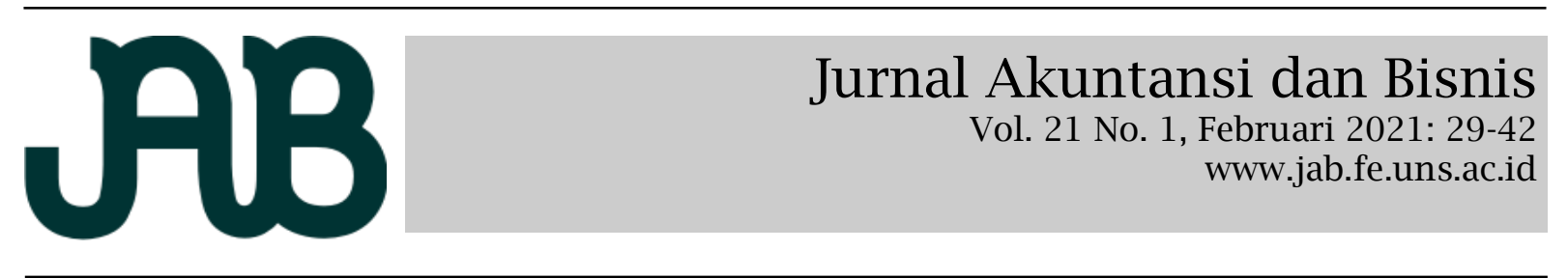

\title{
KEPEMILIKAN SAHAM ASING, DEWAN KOMISARIS ASING DAN DIREKSI ASING TERHADAP PENGHINDARAN PAJAK DI INDONESIA
}

\author{
SITI MAISAROH \\ DODDY SETIAWAN (doddy.setiawan@staff.uns.ac.id)
}

Program Studi Akuntansi, Fakultas Ekonomi dan Bisnis, Universitas Sebelas Maret, Indonesia

\begin{abstract}
A B S T R A C T
This study aims at examining the effect of foreign interest on tax avoidance in Indonesia. The sample of the study consists of the non-financial listed firms in Indonesia Stock Exchange during 2017-2019. There are 911 firm-year observations for the study. The independent variable of the study is foreign interest that consists of foreign ownership, foreign board of commissioners, and foreign board of directors towards tax avoidance in Indonesia. The dependent variable is tax avoidance conducted by non-financial firms. The result of the study shows that that foreign ownership and foreign commissioners have a negative effect on tax avoidance. Therefore, the higher foreign ownership in the ownership structure provides a negative impact on tax avoidance. Foreign ownership pushes management to minimize tax avoidance. Further, the foreign commissioner also negatively affects tax avoidance. Meanwhile, foreign directors have no effect on avoidance in Indonesia. It can be concluded that the foreign parties have a significant effect on tax avoidance, specifically foreign ownership and foreign commissioners. The higher the foreign share ownership and the number of foreign commissioners on the board of commissioners, the lower the tax avoidance practice in Indonesia.

Keywords: foreign ownership, foreign board of commissioners, foreign board of directors, tax avoidance

Penelitian ini memiliki tujuan untuk memberikan bukti empiris tentang dampak keberadaan pihak asing terhadap penghindaran pajak di Indonesia. Sampel penelitian ini adalah perusahaan non-keuangan di Bursa Efek Indonesia periode 2017 hingga 2019. Jumlah sampel penelitian sebanyak 911 perusahaan-tahun. Variabel independen penelitian ini adalah keberadaan asing yang diwakili dengan kepemilikan saham asing, komisaris asing, dan direktur asing di perusahaan tersebut, sedangkan variabel dependen adalah penghindaran pajak. Hasil penelitian menunjukkan kepemilikan saham asing dan komisaris asing berpengaruh negatif terhadap penghindaran pajak. Hal ini menunjukkan keberadaan pihak asing di jajaran pemegang saham memberikan tekanan kepada manajemen untuk mengurangi penghindaran pajak. Selanjutnya, komisaris yang merupakan warga negara asing juga memberikan dampak negatif terhadap penghindaran pajak. Direksi asing tidak memberikan dampak signifikan terhadap penghindaran pajak. Hasil penelitian ini menunjukkan keberadaan pihak asing, terutama kepemilikan saham dan proporsi di dewan komisaris memberikan dampak negatif terhadap praktik penghindaran pajak.

Kata kunci: kepemilikan saham asing, dewan komisaris asing, direksi asing, penghindaran pajak
\end{abstract}

\section{PENDAHULUAN}

Perpajakan menjadi sektor penting yang menyokong pendapatan negara karena tidak hanya menjalankan fungsi anggaran tetapi juga sebagai alat pengatur dan pelaksana kebijakan pemerintah pada bidang sosial-ekonomi (Mardiasmo, 2016). Kesadaran dan peran aktif dari masyarakat (wajib pajak) terhadap ketentuan perpajakan menjadi hal penting agar terimplementasi secara optimal. Namun, pengusaha tidak ingin melakukan kesalahan pembayaran dan kelebihan melakukan pembayaran sehingga akan memanfaatkan peluang sebaik mungkin untuk memberikan keuntungan pada usahanya (Muljono, 2009).

Salah satu faktor yang sangat penting guna mendorong penerimaan negara dari sektor pajak serta menekan praktik 
penghindaran pajak yang agresif di Indonesia adalah kepatuhan Wajib Pajak. Di Indonesia, tingkat kepatuhan Wajib Pajak tergolong masih rendah dibandingkan dengan standar yang ditetapkan oleh Organisation for Economic Co-operation and Development (OECD) yakni sekitar 85\%. Berikut realisasi rasio kepatuhan Wajib Pajak berdasarkan data Direktorat Jenderal Pajak, wajib SPT PPh 2015 sebanyak 60\%, wajib SPT PPh 2016 sebesar 61\%, wajib SPT PPh 2017 sejumlah 73\%, wajib SPT PPh 2018 sebesar 71\%, dan wajib SPT PPh 2019 sebesar 73\%. Dengan demikian, permasalahan perpajakan yang dihadapi Indonesia adalah tingkat kepatuhan dari Wajib Pajak yang masih memerlukan perbaikan. Pengusaha tidak ingin melakukan kesalahan pembayaran dan kelebihan melakukan pembayaran sehingga akan memanfaatkan peluang semaksimal mungkin untuk memberikan keuntungan pada usahanya (Muljono, 2009).

Teori cost and benefit adalah teori yang memberikan evaluasi pada keputusan melalui pertimbangan mendalam mengenai konsekuensi yang kemungkinan akan ditimbulkan (Dreze \& Stern, 1987). Penghindaran pajak merupakan perilaku yang harus mempertimbangkan cost and benefit dengan serius. Jika biaya yang timbul dari praktik penghindaran lebih besar daripada manfaatnya, maka penghindaran pajak tidak perlu dilaksanakan. Salah satu keuntungan yang paling nyata dari praktik penghindaran pajak adalah penghematan arus kas yang membuat arus kas yang mengalir ke perusahaan semakin besar dan pada akhirnya meningkatkan nilai perusahaan (Annuar, Salihu \& Sheikh Obid, 2014). Di samping itu, salah satu cost yang kemungkinan ditimbulkan adalah biaya konsultan pajak atau akuntan yang tinggi.

Globalisasi ekonomi sangat berpengaruh pada tingginya tingkat investasi antar negara, khususnya Foreign Direct Investment (FDI). Salah satu keberhasilan negara maju adalah kemampuan mereka dalam memasok modal, utamanya dalam bentuk FDI. Terdapat bermacam-macam pertimbangan yang mendasari negaranegara maju berinvestasi pada negara berkembang diantaranya yaitu meningkatkan keuntungan, beban tenaga kerja yang relatif lebih murah, dan bahan baku yang mudah diakses karena berdekatan dengan sumbernya.

Di sisi lain, bagi negara tujuan investasi, adanya investor asing yang berbentuk FDI juga memberikan banyak keuntungan. Adanya pengalihan teknologi yang lebih canggih, tenaga kerja yang lebih berpengalaman dan terlatih, kemampuan organisasi dan manajerial yang lebih baik, dan yang tidak kalah pentingnya adalah pemasukan kas negara dari penerimaan pajak yang diperoleh dari keuntungan investor asing. Banyaknya pengaruh positif yang didapat dari investor asing, Indonesia sebagai salah satu negara berkembang juga turut aktif memberikan berbagai insentif agar menarik sebanyak-banyaknya investor asing untuk menanamkan modalnya di Indonesia. Menurut data Badan Pusat Statistik Indonesia pada tahun 2017 sampai dengan 2019 realisasi penanaman modal asing (PMA) menunjukkan tren yang menurun tetapi masih lebih tinggi dari penanaman modal dalam negeri (PMDN). Realisasi penanaman modal pada tahun 2019 oleh PMDN sebesar 52,39\% sementara realisasi PMA sebesar 54,84\%.

Banyak perusahaan yang dimiliki oleh asing melakukan penunggakan pajak dalam jangka waktu yang relatif lama karena memberikan laporan bahwa perusahaan mengalami kerugian dalam SPT Tahunan PPh Badannya (Rahayu, 2010). PMA melakukan penghindaran pajak dengan cara mengurangi jumlah penghasilan sehingga menghasilkan laba yang lebih rendah. Hal ini akan berdampak pada pembayaran pajak yang lebih rendah daripada seharusnya. Hal ini ditunjukkan dengan banyaknya PMA yang melaporkan kerugian selama 10 tahun terakhir tapi tetap mampu beroperasi dan tidak mengalami kebangkrutan (Humas Setkab, 2016).

Reformasi perpajakan dilakukan untuk meningkatkan penerimaan negara dengan memperbaiki peluang (loopholeloophole) yang masih banyak dimanfaatkan Wajib Pajak dalam praktik penghindaran pajak (Suandy, 2014). Peraturan Menteri 
Keuangan Republik Indonesia Nomor 19/ PMK.03/2018 Tentang Perubahan Kedua atas Peraturan Menteri Keuangan Nomor 70/PMK.03/2017 Tentang Petunjuk Teknis Mengenai Akses Informasi Keuangan untuk Kepentingan Perpajakan merupakan salah satu payung hukum yang diciptakan untuk meminimalisir penghindaran pajak perusahaan multinasional di Indonesia. Peraturan ini menjadi acuan pelaksanaan kerjasama antar negara anggota OECD dalam hal pertukaran informasi perpajakan otomatis atau Automatic Exchange of Information (AEOI). Pasal 1 ayat 2 PMK 19/ PMK.03/2018 Tentang Perubahan Kedua atas Peraturan Menteri Keuangan Nomor 70/PMK.03/2017 Tentang Petunjuk Teknis Mengenai Akses Informasi Keuangan untuk Kepentingan Perpajakan menyebutkan bahwa peraturan informasi didasarkan pada perjanjian internasional dengan tujuan pencegahan penghindaran pajak, pencegahan pengelakan pajak, pencegahan penyalahgunaan $\mathrm{P} 3 \mathrm{~B}$, dan penggalian informasi mengenai pemenuhan kewajiban perpajakan.

Pengesahan Undang-undang Nomor 11 Tahun 2020 tentang Cipta Kerja pada 5 Oktober 2020 mewujudkan upaya pemerintah untuk meningkatkan Pendapatan Domestik Bruto (PDB) dengan cara menarik investasi asing untuk berinvestasi langsung di Indonesia. Dalam undang-undang tersebut terdapat poinpoin yang menjadi angin segar bagi investor asing, di antaranya: penyederhanaan perizinan berusaha, persyaratan investasi, ketenagakerjaan, dan kemudahan berusaha. Kebijakan yang dibuat terkait insentif untuk investor asing diberikan semata-mata untuk menarik minat berinvestasi di Indonesia setelah adanya skema AEOI.

Perusahaan dengan struktur kepemilikan asing melakukan aktivitas bisnis secara ekstensif di berbagai negara. Oleh karena itu, komisaris yang paham mengenai aktivitas bisnis secara global sangat dibutuhkan dan tentunya mereka adalah warga negara asing. Komisaris dan direktur asing yang ditempatkan pada perusahaan akan membantu investor asing untuk melakukan pengawasan sehingga dapat memastikan kepentingan mereka akan terlindungi. Perusahaan yang dimiliki oleh asing akan cenderung melakukan tata kelola perusahaan yang baik (Khanna \& Palepu, 2000), tetapi tidak dapat dipungkiri bahwa pihak asing juga tertarik pada keuntungan maksimal, agar pajak yang dibayarkan serendah mungkin.

Penelitian mengenai kepentingan asing pada penghindaran pajak juga dilakukan oleh Salihu, Annuar \& Sheikh Obid (2015) di negara berkembang dengan sampel perusahaan yang ada di Malaysia. Penelitian tersebut memberikan hasil bahwa kepemilikan asing dan direktur asing memiliki pengaruh positif pada penghindaran pajak. Sejalan dengan penelitian tersebut, Kusbandiyah \& Norwani (2018) juga menemukan bahwa kepemilikan asing yang besar akan memberikan dampak yang besar pula terhadap praktik penghindaran pajak pada perusahaan manufaktur di Indonesia. Berbeda dengan Nainggolan dan Sari (2020) yang menemukan bahwa perusahaan yang dimiliki asing berpengaruh negatif terhadap praktik penghindaran pajak. Sementara itu, Rusydi \& Martani (2014) mempelajari dampak kepemilikan asing terhadap penghindaran pajak di Indonesia dan gagal membuktikan bahwa kepemilikan asing berdampak pada praktik penghindaran pajak.

Penelitian serupa yang mengkaji kepemilikan asing dan direktur asing oleh Nadhir (2015) memberikan hasil bahwa kepemilikan saham asing berpengaruh positif pada penghindaran perusahaan yang listing di Indonesian Stock Exchange. Sedangkan untuk variabel direktur asing, Nadhir (2015) tidak bisa membuktikan pengaruhnya terhadap praktik penghindaran pajak. Berbeda dengan Nainggolan dan Sari (2020) yang menemukan bahwa direksi asing berpengaruh positif pada praktik penghindaran pajak. Lebih lanjut, penelitian yang dilakukan oleh Suranta, Midiastuty \& Hasibuan (2020) juga memberikan bukti bahwa investor asing memiliki pengaruh positif pada praktik penghindaran pajak dan komisaris asing tidak berdampak pada penghindaran pajak. 
Perbedaan hasil pada penelitian sebelumnya (Rusydi \& Martani, 2014; Salihu et al., 2015; Suranta et al., 2020; Alkurdi \& Mardini,2020; Shi, Concepcion, Laguinday, Ong Hian Huy \& Unite, 2020) dapat terjadi karena perbedaan pengukuran variabel dependennya yaitu penghindaran pajak yang menggunakan Effective Tax Rate (ETR)= (GAAP/Cash ETR). Penelitian ini mengikuti penelitian Arieftiara (2017) yang mengemukakan bahwa total Book Tax Difference (BTD) merupakan alat pengukuran yang lebih baik daripada ETR (GAAP/Cash ETR). Lebih lanjut lagi, penelitian ini mengunakan pengujian tambahan dan pemeriksaan ketahanan untuk mendukung serta melihat konsistensi hasil pengujian utama.

Secara spesifik penelitian ini mengkaji dampak kepemilikan perusahaan oleh pihak asing. Selain itu, peneliti juga mengkaji pentingnya keberadaan warga negara asing pada direksi dan dewan komisaris terhadap tindakan perusahaan dalam melakukan penghindaran pajak. Penelitian ini menggunakan penelitian Salihu et al. (2015) sebagai acuan utama karena peneliti tertarik untuk menerapkan tema penelitian yang berhubungan dengan keterlibatan asing dan penghindaran pajak di Indonesia mengingat vitalnya sektor perpajakan dan tingginya foreign direct investment di Indonesia.

Berbeda dari penelitian sebelumnya (Rusydi \& Martani, 2014; Salihu et al., 2015; Idzni \& Purwanto, 2017; Kusbandiyah \& Norwani, 2018; Nainggolan \& Sari, 2020; dan Suranta et al., 2020) yang mengkaji perilaku penghindaran pajak perusahaan PMA pada periode sebelum diterapkannya Peraturan Menteri Keuangan Republik Indonesia Nomor 19/PMK.03/2018 Tentang Perubahan Kedua atas Peraturan Menteri Keuangan Nomor 70/PMK.03/2017 Tentang Petunjuk Teknis Mengenai Akses Informasi Keuangan untuk Kepentingan Perpajakan yang merupakan salah satu payung hukum guna meminimalisir praktik penghindaran pajak perusahaan PMA di Indonesia, penelitian ini menggunakan periode setelah pengesahan peraturan tersebut, yaitu tahun 2017-2019. Diharapkan penelitian ini dapat menjadi referensi atau bahan per- bandingan oleh pemerintah mengenai tingkat penghindaran pajak yang dilakukan Wajib Pajak Badan di Indonesia. Dengan begitu, Direktorat Jenderal Pajak selaku regulator dapat mengevaluasi celah (loophole) yang masih ada pada peraturan perundang-undangan perpajakan serta mengevaluasi efektivitas kebijakan yang dibuat.

Selain itu, penelitian ini menambahkan variabel independen dewan komisaris asing karena belum banyak studi yang meneliti pengaruh dewan komisaris terhadap penghindaran pajak. Suranta et al. (2015) telah melakukan studi yang mengkaji pengaruh dewan komisaris terhadap penghindaran pajak. Hasil penelitian tersebut menunjukkan bahwa dewan komisaris tidak berpengaruh terhadap penghindaran pajak.

Organisasi penulisan pada penelitian ini, pertama adalah pendahuluan yang menyajikan latar belakang serta tujuan penelitian. Selanjutnya adalah tinjauan teoritis yang menyajikan penjelasan mengenai penghindaran pajak, kepemilikan asing, dewan komisaris, dan direksi asing serta keterkaitannya dengan teori cost and benefit sehingga dapat menjadi landasan untuk pengembangan hipotesis. Kemudian, bagian ketiga pada penelitian ini menjelaskan mengenai metode penelitian yang memaparkan model, operasionalisasi variabel, dan teknik pengolahan data. Pada bagian akhir penelitian ini berisi kesimpulan, keterbatasan, dan saran.

\section{TINJAUAN PUSTAKA DAN PENGEM- BANGAN HIPOTESIS}

Perusahaan yang dimiliki oleh asing akan cenderung melakukan tata kelola perusahaan yang baik (Khanna \& Palepu, 2000), tetapi tidak dapat dipungkiri bahwa pihak asing juga tertarik pada keuntungan yang sebanyak-banyaknya, agar pajak yang dibayarkan serendah mungkin. Sesuai teori cost and benefit yang memberikan evaluasi pada keputusan melalui pertimbangan mendalam mengenai konsekuensi yang kemungkinan akan ditimbulkan (Dreze \& Stern, 1987). Salah satu keuntungan yang paling nyata dari praktik penghindaran pajak adalah penghematan arus kas yang 
membuat arus kas yang mengalir ke perusahaan semakin besar dan pada akhirnya meningkatkan nilai perusahaan (Annuar et al., 2014). Menurut pemegang saham perusahaan, keuntungan yang dihasilkan dari menerapkan praktik penghindaran pajak memberikan sinyal bahwa dividen yang didapatkan akan lebih besar. Bagi manajemen, hasil dari praktik penghindaran pajak yang membuat laba sesungguhnya lebih besar akan meningkatkan pula insentif atau bonus pada jabatan manajerial.

Selain keuntungan, tidak dapat dipungkiri bahwa penghindaran pajak juga akan menimbulkan cost bagi perusahaan. Reputasi perusahaan akan menjadi taruhannya jika masyarakat memiliki kepedulian yang tinggi pada perusahaan sehingga hal tersebut secara tidak langsung akan mengancam eksistensi perusahaan (Annuar et al., 2014). Penelitian yang dilakukan (Hanlon\&Slemrod, 2009) membuktikan bahwa perusahaan yang diisukan melakukan penghindaran pajak, rata-rata harga saham perusahaan tersebut akan menurun drastis. Selain itu, cost yang dapat ditimbulkan dari kegiatan penghindaran pajak yaitu biaya konsultan pajak yang tinggi karena penggunaan jasa konsultan dan akuntan yang handal guna merencanakan strategi perpajakan yang dapat membuat beban pajak rendah, relatif mematok tarif konsultasi yang tinggi karena tingkat kompleksitas transaksi yang tinggi. Selain itu, jasa konsultan pajak atau akuntan perusahaan PMA dapat menjadi mahal karena kemungkinan penggunaan jasa penerjemah untuk konsultasi. Jika tidak menggunakan jasa penerjemah, kemampuan konsultan pajak dalam multibahasa juga menjadi faktor penting untuk menjalin kerjasama yang baik dengan perusahaan multinasional sehingga patut untuk mematok harga yang tinggi.

Nainggolan \& Sari (2020) menemukan bahwa kepemilikan asing berdampak negatif pada praktik penghindaran pajak. Penelitian tersebut menunjukkan bahwa walaupun perusahaan dikuasai oleh entitas asing, pemegang saham tetap mengharapkan manfaat nilai jangka panjang perusahaan untuk berusaha menciptakan good corporate governance dan mengurangi praktik penghindaran pajak. Didukung oleh teori cost and benefit, pemilik asing lebih memperhatikan cost jangka panjang yang timbul dari praktik penghindaran pajak daripada benefit yang akan dihasilkan.

Salihu et al. (2015), Alkurdi \& Mardini (2020), Shi et al. (2020) dan Annisa et al. (2020) memberikan hasil bahwa adanya pemegang saham asing di perusahaan akan berdampak positif pada perilaku penghindaran pajak, pemilik asing dapat menggunakan skala internasionalnya untuk menghindari perpajakan. Temuan Kusbandiyah \& Norwani (2018) yang sejalan dengan Salihu et al. (2015) mengemukakan bahwa tingginya tingkat kepemilikan asing, memberikan efek peningkatan praktik penghindaran pajak yang akan dilakukan. Sesuai dengan teori cost and benefit (Dreze \& Stern, 1987) yang mengemukakan bahwa pemilik perusahaan akan mempertimbangkan manfaat dan biaya yang timbul dari suatu tindakan. Maka, apabila praktik penghindaran pajak dapat menghasilkan keuntungan yang besar untuk mendapatkan return yang besar daripada biaya yang akan ditimbulkan, pemilik perusahaan akan cenderung menghindari pajak. Semakin besar kepemilikan sahamnya, semakin besar pengaruhnya terhadap pengambilan keputusan masing-masing perusahaan. Berdasarkan teori dan penelitian tersebut, hipotesis 1 dalam penelitian ini adalah:

H1: Kepemilikan oleh asing memiliki pengaruh positif pada praktik penghindaran pajak.

Komisaris asing yang dimaksud dalam penelitian ini merupakan komisaris yang berkewarganegaraan asing. Kehadiran komisaris asing pada struktur dewan perusahaan menunjukkan keragaman dewan. Keragaman ini dapat terjadi karena pengaruh kepemilikan asing yang memungkinkan dewan melindungi kepentingannya (Choi, Sul \& Min, 2012). Sesuai dengan teori cost and benefit (Dreze \& Stern, 1987) yang mengemukakan bahwa pemilik perusahaan akan cenderung memprioritaskan keuntungan yang besar 
untuk mendapatkan return yang besar daripada biaya yang akan ditimbulkan. Semakin besar kepemilikan sahamnya, semakin besar pengaruhnya terhadap pengambilan keputusan sehingga komisaris asing sebagai perwakilan investor asing akan cenderung berperilaku menghindari pajak. Dengan penghindaran pajak maka keuntungan yang dilaporkan tidak sesuai dengan seharusnya sehingga keuntungan seharusnya akan lebih besar daripada yang dilaporkan. Dalam hal ini investor akan diuntungkan.

Studi empiris yang dilakukan Idzni \& Purwanto (2017) menunjukkan bahwa komisaris asing berpengaruh positif terhadap penghindaran pajak. Penelitian tersebut membuktikan bahwa semakin besar jumlah komisaris asing dalam suatu perusahaan maka akan meningkatkan praktik penghindaran pajaknya. Berdasarkan teori dan penelitian tersebut, hipotesis 2 dalam penelitian ini adalah:

H2: Komposisi komisaris asing memiliki pengaruh positif pada penghindaran pajak.

Dalam mewujudkan pengawasan manajemen yang efektif, komposisi dewan direksi menjadi pertimbangan penting (Badertscher, Katz \& Rego, 2013). Siapa pun yang terpilih dan menduduki posisi dewan direksi perwakilan asing dapat memberikan pengaruh yang besar terhadap keputusan bisnis, termasuk perilaku penghindaran pajak perusahaan. Sesuai dengan teori cost and benefit (Dreze \& Stern, 1987) yang mengemukakan bahwa pemilik perusahaan akan cenderung memprioritaskan keuntungan yang besar untuk mendapatkan return yang besar daripada biaya yang akan ditimbulkan. Semakin besar kepemilikan sahamnya, semakin besar pengaruhnya terhadap pengambilan keputusan. Hal tersebut mendorong direksi asing untuk melakukan penghindaran pajak.

Salihu et al. (2015) menemukan bahwa parlemen asing berdampak positif pada praktik penghindaran pajak di Malaysia. Penelitian ini didukung oleh Nainggolan \& Sari (2020) yang menemukan bahwa direksi asing dengan kepentingan jangka pendek berpengaruh positif terhadap tindakan penghindaran pajak. Maka dapat disimpulkan bahwa semakin besar jumlah direktur asing pada dewan direksi di perusahaan PMA, semakin besar pula kecenderungan perusahaan tersebut melakukan penghindaran pajak. Berdasarkan teori dan penelitian tersebut, hipotesis ketiga dari penelitian ini adalah:

H3: Komposisi direktur asing memiliki pengaruh positif pada penghindaran pajak.

\section{METODE PENELITIAN}

Penelitian ini memiliki tujuan untuk memberikan bukti empiris mengenai pengaruh kepemilikan oleh asing, komisaris asing, dan direksi asing pada penghindaran pajak. Jenis penelitian ini termasuk dalam penelitian kuantitatif yang meliputi data pelengkap berupa laporan tahunan dari website Bursa Efek Indonesia (www.idx.co.id) dan Thomas Reuters Eikon dari Fintech Center Universitas Sebelas Maret. Populasi penelitian ini adalah seluruh sektor perusahaan nonkeuangan mulai tahun 2017-2019. Perusahaan keuangan dikecualikan karena memiliki peraturan perpajakan yang berbeda sehingga tidak dapat dijadikan satu dengan industri lain. Dalam penelitian ini pengambilan sampel dilakukan dengan cara purposive sampling, di mana pemilihan sampel dilakukan berdasarkan standar tertentu agar tidak terjadi penyimpangan. Berikut merupakan model regresi yang digunakan pada penelitian ini:

$\begin{aligned} & \text { BTD }_{\mathrm{it}}= \alpha_{0}+\beta_{1} \text { FOROWN }_{\mathrm{i}, \mathrm{t}}+\beta_{2} \text { FORCOM }_{\mathrm{i}, \mathrm{t}}+ \\ & \beta_{3} \text { FORGDIR }_{\mathrm{i}, \mathrm{t}}+\beta_{4} \text { SIZE }_{\mathrm{i}, \mathrm{t}}+\beta_{5} \text { ROA }_{\mathrm{i}, \mathrm{t}}+ \\ & \beta_{6} \mathrm{LEV}_{\mathrm{i}, \mathrm{t}}+\beta_{7} \text { CAPINT }_{\mathrm{i}, \mathrm{t}}+\varepsilon_{\mathrm{i}, \mathrm{t}} \\ & \text { Penelitian ini menggunakan variabel }\end{aligned}$ dependen Book Tax Difference (BTD), yang merupakan selisih antara laba sebelum pajak (laba akuntansi) dan laba kena pajak yang dilaporkan dalam laporan keuangan. Total BTD dapat menangkap selisih laporan laba rugi berdasarkan nilai aslinya, sehingga memberikan keuntungan bagi pemegang saham untuk dapat mengontrol kinerja perusahaan dan memodifikasi laporan laba rugi untuk memenuhi keinginan perusahaan dalam menghindari pajak serta dapat mengurangi penghasilan 
kena pajak (Arieftiara, 2017). Berdasarkan penjelasan tersebut maka dapat dikatakan bahwa BTD sebagai alat pengukuran penghindaran pajak lebih baik daripada menggunakan ETR GAAP / Cash ETR) yang banyak digunakan pada penelitian sebelumnya (Rusydi \& Martani, 2014; Salihu et al., 2015; Suranta et al., 2020; Alkurdi \& Mardini, 2020; Shi et al., 2020).

\section{ANALISIS DAN PEMBAHASAN}

Penelitian ini menggunakan populasi perusahaan yang terdaftar di Bursa Efek Indonesia (BEI) selama tahun 2017 hingga

Tabel 1.

Operasionalisasi Variabel Penelitian

\begin{tabular}{|c|c|c|}
\hline Variabel & Penelitian & Definisi dan Pengukuran \\
\hline \multicolumn{3}{|l|}{ Dependen } \\
\hline Penghindaran Pajak & $\begin{array}{l}\text { Comprix, } \\
\text { Graham \& } \\
\text { Moore }(2011)\end{array}$ & $\begin{array}{l}\text { Book tax difference (BTD) merupakan } \\
\text { perbedaan antara laba akuntansi dengan } \\
\text { laba fiskal. } \\
\text { BTDit = BIit - }\left[\frac{C T E_{\text {it }}}{S T R_{\mathrm{t}}}\right] \\
\text { Dimana: } \\
\text { BIit= laba akuntansi sebelum pajak } \\
\text { perusahaan i pada tahun t; } \\
\text { CTEit= beban pajak saat ini untuk } \\
\text { perusahaan i pada tahun t; } \\
\text { STRit= statutory tax rate (tarif PPh badan } \\
\text { sesuai UU PPh), tahun t; }\end{array}$ \\
\hline $\begin{array}{l}\text { Kepemilikan oleh Asing } \\
\text { (FOROWN) }\end{array}$ & $\begin{array}{l}\text { Salihu et al., } \\
(2015)\end{array}$ & $\begin{array}{l}\text { Modal yang bersumber dari negara as- } \\
\text { ing, perseorangan asing dan badan } \\
\text { hukum di Indonesia yang sebagian atau } \\
\text { seluruh modalnya dari pihak asing. } \\
\text { FOROWN= Jumlah saham yang dimiliki } \\
\text { asing dibagi total saham yang beredar }\end{array}$ \\
\hline Komisaris Asing (FORCOM) & $\begin{array}{l}\text { Salihu et al., } \\
(2015)\end{array}$ & $\begin{array}{l}\text { Proporsi komisaris yang berkewarga- } \\
\text { negaraan asing. } \\
\text { FORCOM= Jumlah komisaris asing dibagi } \\
\text { total komisaris }\end{array}$ \\
\hline Direksi Asing (FORGDIR) & $\begin{array}{l}\text { Salihu et al., } \\
\text { (2015) }\end{array}$ & $\begin{array}{l}\text { Proporsi direktur yang berkewarganega- } \\
\text { raan asing. } \\
\text { FORGDIR= Jumlah direktur asing dibagi } \\
\text { total dewan direksi. }\end{array}$ \\
\hline \multicolumn{3}{|l|}{ Kontrol } \\
\hline Ukuran Perusahaan (SIZE) & $\begin{array}{l}\text { Richardson dan } \\
\text { Taylor (2012) }\end{array}$ & $\begin{array}{l}\text { Sebuah ukuran yang menggambarkan } \\
\text { besar kecilnya perusahaan. } \\
\text { SIZE= Ln (Total Aset) }\end{array}$ \\
\hline Return on Asset (ROA) & $\begin{array}{l}\text { Richardson dan } \\
\text { Taylor (2012) }\end{array}$ & $\begin{array}{l}\text { Kemampuan perusahaan dalam } \\
\text { menghasilkan laba. } \\
\text { ROA= Laba sebelum pajak dibagi total } \\
\text { aset }\end{array}$ \\
\hline Leverage (LEV) & $\begin{array}{l}\text { Salihu et al., } \\
(2015)\end{array}$ & $\begin{array}{l}\text { Kemampuan perusahaan untuk mengel- } \\
\text { ola aset dari pinjaman (kreditor). } \\
\text { LEV= Total hutang dibagi total aset }\end{array}$ \\
\hline Intensitas Modal (CAPINT) & $\begin{array}{l}\text { Richardson dan } \\
\text { Taylor (2012) }\end{array}$ & $\begin{array}{l}\text { Besaran aset perusahaan yang diinves- } \\
\text { tasikan dalam bentuk aktiva tetap. } \\
\text { CAPINT= net property, plant, and equip- } \\
\text { ment dibagi total aset periode sebe- } \\
\text { lumnya }\end{array}$ \\
\hline
\end{tabular}


2019. Sampel yang digunakan merupakan seluruh sektor perusahaan yang terdaftar kecuali sektor keuangan yang terdiri dari bank, institusi keuangan, perusahaan sekuritas, asuransi, dan lainnya. Sampel ditentukan dengan metode purposive sampling. Jumlah data observasi yang digunakan dalam penelitian ini sebanyak 911 perusahaan-tahun.

Tabel 3 memberikan informasi statistik deskriptif penelitian ini. Variabel BTD menunjukkan nilai antara $-2,160$ sampai 0,710 dengan rata-rata sebesar 0,06 (6\%). Rata-rata kepemilikan asing sebesar 24,56 dengan nilai terendah sebesar 0 dan tertingginya sebesar 99,79. Hal tersebut menunjukkan bahwa terdapat perusahaan di Indonesia yang hampir seluruh sahamnya dimiliki oleh asing. Pada penelitian ini, terdapat perusahaan yang memiliki dewan komisaris dan dewan direksi yang sepenuhnya diduduki oleh warga negara asing, namun ada juga yang sama sekali susunan dewannya tidak diduduki oleh warga negara asing. Ratarata dewan komisaris asing dan dewan direksi asing, masing-masing sebesar 0,078 (7,8\%) dan 0,113 (11,3\%).

Dari Tabel 4, dapat diketahui bahwa kepemilikan asing menunjukkan nilai koefisien sebesar $-0,0005$ dengan level signifikansi $0,0000(\alpha<0,01)$. Hal ini berarti kepemilikan asing berpengaruh negatif terhadap penghindaran pajak sehingga H1 ditolak. Semakin besar kepemilikan saham asing, semakin kecil upaya penghindaran pajak yang dilakukan. Hasil ini sejalan dengan Nainggolan \& Sari (2020) yang menggunakan variabel dummy untuk mewakili kepemilikan asing signifikan dan menghasilkan temuan bahwa kepemilikan asing signifikan berpengaruh negatif terhadap agresivitas pajak.

Dengan kata lain, perusahaan dengan kepemilikan asingnya yang signifikan

Tabel 2.

Pemilihan Sampel yang Digunakan

\begin{tabular}{lcccc}
\hline \multicolumn{1}{c}{ Keterangan } & Tahun & & Total \\
\hline $\begin{array}{l}\text { Total Perusahaan Terdaftar di BEI selain sektor } \\
\text { keuangan }\end{array}$ & 446 & 516 & 548 & 1510 \\
$\begin{array}{l}\text { Dikurangi: } \\
\text { Perusahaan yang mengalami kerugian }\end{array}$ & $(69)$ & $(54)$ & (83) & (214) \\
$\begin{array}{l}\text { Perusahaan yang datanya tidak tersedia lengkap } \\
\text { Jumlah sampel (perusahaan-tahun) }\end{array}$ & $(75)$ & $(138)$ & $(172)$ & (385) \\
\hline
\end{tabular}

Tabel 3.

Statistik Deskriptif

\begin{tabular}{lccccc}
\hline \multicolumn{1}{c}{ Variabel } & $\mathbf{N}$ & Mean & Std Dev. & Min & Max \\
\hline BTD & 911 & 0,066 & 0,116 & $-2,160$ & 0,710 \\
FOR_OWN & 911 & 24,56 & 28,94 & 0,000 & 99,79 \\
FOR_COM & 911 & 0,078 & 0,193 & 0,000 & 1,000 \\
FORG_DIR & 911 & 0,113 & 0,209 & 0,000 & 1,000 \\
SIZE & 911 & 21,96 & 167,1 & 15,30 & 26,57 \\
ROA & 911 & 0,091 & 0,085 & 0,000 & 0,730 \\
LEV & 911 & 0,188 & 0,189 & 0,000 & 0,930 \\
CAPINT & 911 & 0,378 & 0,278 & 0,000 & 2,070 \\
\hline
\end{tabular}

Definisi variabel: BTD = total book tax difference sesuai Comprix et al. (2011) ; FOR_OWN = proporsi saham asing terhadap total jumlah saham; FOR_COM = proporsi dewan komisaris asing terhadap total dewan komisaris; FORG_DIR = proporsi dewan direksi asing terhadap jumlah keseluruhan dewan; $\mathrm{ROA}=$ rasio laba sebelum pajak pada total aset; SIZE = logaritma natural total aset; $\mathrm{LEV}=$ rasio utang terhadap aset; CAPINT = rasio dari net of property, plant, and equipment pada total aset di periode sebelumnya. 
(minimal 20\%), akan berperilaku taat pajak dengan tidak melakukan praktik penghindaran pajak. Namun, hal tersebut bertentangan dengan penelitian Salihu et al. (2015), Alkurdi \& Mardini (2020), Shi et al. (2020) dan Annisa et al. (2020) yang menemukan bahwa semakin besar proporsi saham yang dimiliki asingmaka akan semakin meningkatkan intensi pelaksanaan praktik penghindaran pajak. Dari hasil tersebut dapat disimpulkan bahwa pemilik asing lebih memilih untuk taat aturan dan tidak menghindari pajak, karena pemilik asing sangat mempertimbangkan cost yang timbul dari praktik penghindaran pajak. Risiko hukum, reputasi perusahaan, dan biaya konsultasi perpajakan menjadi penghambat praktik penghindaran pajak.

Komposisi dewan komisaris asing juga menunjukkan adanya pengaruh negatif terhadap penghindaran pajak. Hal tersebut ditunjukkan oleh koefisien komisaris asing sebesar -0,0039 dan 0,0388 dengan level signifikansi sebesar $0,0000(\alpha<0,01)$. Hasil pengujian ini membuktikan bahwa keberadaan komisaris asing akan semakin meningkatkan kepatuhan pada peraturan perpajakan sehingga cenderung untuk tidak melakukan praktik penghindaran pajak. Sependapat dengan pemilik atau pemegang saham asing, komisaris asing juga lebih mementingkan cost yang akan ditimbulkan jika melakukan penghindaran pajak. Cost berupa risiko hukum dan reputasi tersebut akan sangat berbahaya pada kelangsungan hidup perusahaan dalam jangka waktu yang panjang daripada benefit yang akan didapatkan. Selain itu cost yang timbul saat melakukan perencanaan pajak dengan menghindari pajak dan menggunakan jasa konsultan pajak atau akuntan juga sangat dipertimbangkan karena kompetensi konsultan pajak atau akuntan harus lebih ahli dalam menangani perusahaan multinasional. Penelitian ini berhasil melengkapi Suranta et al. (2020) yang tidak berhasil membuktikan pengaruh dewan komisaris asing

Tabel 4.

Pengaruh Kepemilikan Asing, Dewan Komisaris Asing dan Dewan Direksi Asing pada Penghindaran Pajak

\begin{tabular}{|c|c|c|c|c|}
\hline & 1 & 2 & 3 & 4 \\
\hline \multirow[t]{2}{*}{$\mathrm{C}$} & $-0,3327$ & $-0,3370$ & $-0,3416$ & $-0,3325$ \\
\hline & $(0,0000)$ & $(0,0000)$ & $(0,0000)$ & $(0,0000)$ \\
\hline \multirow[t]{2}{*}{ FOR_OWN } & $-0,0005 *$ & & & $-0,0005 * * * ;$ \\
\hline & $(0,0000)$ & & & $(0,0000)$ \\
\hline \multirow{2}{*}{ FOR_COM } & & $-0,0388 * * * *$ & & $-0,0039 * * *$ \\
\hline & & $(0,0005)$ & & $(0,0022)$ \\
\hline \multirow[t]{2}{*}{ FORG_DIR } & & & 0,0038 & 0,0149 \\
\hline & & & $(0,4256)$ & $(0,2632)$ \\
\hline \multirow[t]{2}{*}{ SIZE } & $0,0001 * * * *$ & $0,0001 * * *$ & $0,0001 * * *$ & $0,0001 * * *$ \\
\hline & $(0,0000)$ & $(0,0000)$ & $(0,0000)$ & $(0,0000)$ \\
\hline \multirow[t]{2}{*}{ ROA } & $0,5938 * * *$ & $0,5977 * * *$ & $0,5956 * * *$ & $0,5973 * * *$ \\
\hline & $(0,0000)$ & $(0,0000)$ & $(0,0000)$ & $(0,0000)$ \\
\hline \multirow[t]{2}{*}{ LEV } & $-0,1689 * * *$ & $-0,1661 * * *$ & $-0,1675 * * *$ & $-0,1671^{* * * *}$ \\
\hline & $(0,0000)$ & $(0,0000)$ & $(0,0000)$ & $(0,0000)$ \\
\hline \multirow[t]{2}{*}{ CAPINT } & 0,0268 & 0,0279 & 0,0278 & 0,0272 \\
\hline & $(0,1733)$ & $(0,1637)$ & $(0,1686)$ & $(0,1748)$ \\
\hline Adjusted $\mathrm{R}^{2}$ & 0,5125 & 0,5122 & 0,5119 & 0,51104 \\
\hline F-Statistic & 3,7979 & 3,7940 & 3,7916 & 3,7648 \\
\hline Prob (F-Statistic) & 0,0000 & 0,0000 & 0,0000 & 0,0000 \\
\hline Observation & 911 & 911 & 911 & 911 \\
\hline
\end{tabular}

Definisi variabel: BTD = total book tax difference sesuai Comprix et al. (2011); FOR_OWN = proporsi saham asing terhadap total jumlah saham; FOR_COM = proporsi dewan komisaris asing terhadap total dewan komisaris; FORG_DIR = proporsi dewan direksi asing terhadap jumlah keseluruhan dewan; ROA = rasio laba sebelum pajak pada total aset; SIZE = logaritma natural total aset; LEV = rasio utang terhadap aset; CAPINT = rasio dari net of property, plant, and equipment pada total aset di periode sebelumnya.

$* * * * * *$ masing-masing signifikan pada $1 \%, 5 \%, 10 \%$ 
terhadap praktik penghindaran pajak. Hasil penelitian ini bertentangan dengan penelitian yang dilakukan Idzni \& Purwanto (2017) yang mengemukakan bahwa semakin tinggi jumlah dewan komisaris asing pada perusahaan maka semakin tinggi pula praktik penghindaran pajak.

PMK 19/PMK.03/2018 Tentang Perubahan Kedua atas Peraturan Menteri Keuangan Nomor 70/PMK.03/2017 Tentang Petunjuk Teknis Mengenai Akses Informasi Keuangan untuk Kepentingan Perpajakan yang diberlakukan pada 23 Agustus 2017 menjadi acuan pelaksanaan kerja sama antar negara anggota OECD dalam hal pertukaran informasi perpajakan otomatis atau AEOI. Pasal 1 ayat 2 PMK 19/ PMK.03/2018 Tentang Perubahan Kedua atas Peraturan Menteri Keuangan Nomor 70/PMK.03/2017 Tentang Petunjuk Teknis
Mengenai Akses Informasi Keuangan untuk Kepentingan Perpajakan menyebutkan bahwa peraturan informasi didasarkan pada perjanjian internasional dengan tujuan pencegahan penghindaran pajak, pencegahan pengelakan pajak, pencegahan penyalahgunaan $\mathrm{P} 3 \mathrm{~B}$, dan penggalian informasi mengenai pemenuhan kewajiban perpajakan. Dalam pelaksanaannya, tujuan peraturan ini dapat didukung dengan hasil pengujian pada penelitian ini, yang menyatakan bahwa kepemilikan asing dan dewan komisaris asing cenderung berperilaku taat terhadap pajak.

Penerbitan PMK 19/PMK.03/2018 Tentang Perubahan Kedua atas Peraturan Menteri Keuangan Nomor 70/PMK.03/2017 Tentang Petunjuk Teknis Mengenai Akses Informasi Keuangan untuk Kepentingan Perpajakan yang merupakan salah satu

Tabel 5.

Pengaruh Kepemilikan Asing, Dewan Komisaris Asing dan Dewan Direksi Asing pada Penghindaran Pajak (Perbandingan dengan Model Regresi Non-linier)

\begin{tabular}{lcccc}
\hline & $\mathbf{1}$ & $\mathbf{2}$ & $\mathbf{3}$ & $\mathbf{4}$ \\
\hline C & $-0,3327$ & $-0,3325$ & $-0,3413$ & $-0,3397$ \\
FOR_OWN & $(0,0000)$ & $(0,0000)$ & $(0,0000)$ & $(0,0000)$ \\
FOR_OWN2 & $-0,0005^{* * * *}$ & $-0,0005^{* * * *}$ & & \\
& $(0,0000)$ & $(0,0000)$ & $-2,4389 * * *$ & \\
FOR_COM & & & $-2,2460^{* * * *}$ \\
FORG_DIR & & & $(0,0003)$ & $(0,0000)$ \\
& & $-0,0039^{* * * *}$ & & $-0,0399^{* * * *}$ \\
SIZE & & $(0,0022)$ & & $(0,0047)$ \\
& & 0,0149 & & 0,0119 \\
ROA & $(0,2632)$ & & $(0,3111)$ \\
& $0,0001^{* * * *}$ & $0,0001^{* * * *}$ & $0,0001^{* * * *}$ & $0,0001^{* * * *}$ \\
LEV & $(0,0000)$ & $(0,0000)$ & $(0,0000)$ & $(0,0000)$ \\
& $0,5938^{* * * *}$ & $0,5973^{* * * *}$ & $0,5945^{* * * *}$ & $0,5977^{* * * *}$ \\
CAPINT & $(0,0000)$ & $(0,0000)$ & $(0,0000)$ & $(0,0000)$ \\
& $-0,1689^{* * * *}$ & $-0,1671^{* * * *}$ & $-0,1685^{* * * *}$ & $-0,1667^{* * * *}$ \\
Adjusted R & $(0,0000)$ & $(0,0000)$ & $(0,0000)$ & $(0,0000)$ \\
F-Statistic & 0,0268 & 0,0272 & 0,0274 & 0,0278 \\
Prob (F-Statistic) & $(0,1733)$ & $(0,1748)$ & $(0,1684)$ & $(0,1702)$ \\
Observation & 0,5125 & 0,51104 & 0,5120 & 0,5105 \\
\hline Ketengan: BTD & 3,7979 & 3,7648 & 3,7927 & 3,7597 \\
& 0,0000 & 0,0000 & 0,0000 & 0,0000 \\
& 911 & 911 & 911 & 911 \\
\hline
\end{tabular}

Keterangan: $\mathrm{BTD}=$ total book tax difference sesuai Comprix et al. (2011); FOR_OWN= proporsi saham asing terhadap total jumlah saham; FOR_OWN2= kuadrat dari proporsi saham asing terhadap total jumlah saham; FOR_COM= proporsi dewan komisaris asing terhadap total dewan komisaris; FORG_DIR= proporsi dewan direksi asing terhadap jumlah keseluruhan dewan; $\mathrm{ROA}=$ rasio laba sebelum pajak pada total aset; SIZE= logaritma natural total aset; $\mathrm{LEV}=$ rasio utang terhadap aset; CAPINT= rasio dari net of property, plant, and equipment pada total aset di periode sebelumnya.

$* * * * * *, *$ masing-masing signifikan pada $1 \%, 5 \%, 10 \%$ 
payung hukum guna meminimalisir praktik penghindaran pajak perusahaan PMA di Indonesia tidak memengaruhi perilaku direktur asing dalam praktik penghindaran pajak.

Hasil penelitian yang tidak signifikan ini diduga karena kurangnya spesifikasi direksi asing berdasarkan jabatan fungsionalnya. Data yang digunakan pada variabel ini adalah proporsi direktur asing secara umum sedangkan direktur asing pada perusahaan multinasional ada yang berfungsi sebagai direktur utama maupun direktur keuangan.

Variabel kontrol dalam penelitian ini yaitu ukuran perusahaan dan rasio profitabilitas menunjukkan nilai signifikansi $0,0000 \quad(\alpha<0,01) \quad$ dengan koefisien masing-masing 0,0001 dan 0,5973 sehingga penelitian ini dapat membuktikan bahwa ukuran perusahaan dan rasio profitabilitas berpengaruh positif terhadap penghindaran pajak. Hasil ini sejalan dengan hasil penelitian yang dilakukan oleh Taylor \& Richardson (2012) yang menyatakan bahwa rasio profitabilitas berpengaruh positif pada praktik penghindaran pajak. Sedangkan, rasio leverage yang diproksikan dengan debt to assets berpengaruh negatif terhadap penghindaran pajak dengan koefisien 0,1671 dan nilai signifikansi sebesar $0,0000(\alpha<0,01)$. Penelitian ini tidak dapat membuktikan bahwa intensitas modal berpengaruh pada penghindaran pajak.

Pengujian tambahan dilakukan untuk mendukung hasil pengujian utama serta melihat konsistensinya dengan regresi non linear yang disajikan dalam tabel 5. Regresi non-linear yang digunakan adalah bentuk parabola atau polinum pangkat dua, di mana variabel kepemilikan saham dikuadratkan sesuai dengan teori model non-linear dalam parameter yang dipaparkan oleh Gujarati \& Porter (2009). Hasil pada tabel 5 menunjukkan koefisien

\section{Tabel 6.}

Pengaruh Kepemilikan Asing, Dewan Komisaris Asing dan Dewan Direksi Asing pada Penghindaran Pajak (Robustness Test - Adj. BTD)

\begin{tabular}{|c|c|c|c|c|}
\hline & 1 & 2 & 3 & 4 \\
\hline \multirow[t]{2}{*}{$\mathrm{C}$} & $-0,3836$ & $-0,3887$ & $-0,3933$ & $-0,3839$ \\
\hline & $(0,0000)$ & $(0,0000)$ & $(0,0000)$ & $(0,0000)$ \\
\hline \multirow[t]{2}{*}{ FOR_OWN } & $-0,0005 * * *$ & & & $-0,0005^{* * * *}$ \\
\hline & $(0,0000)$ & & & $(0,0000)$ \\
\hline \multirow[t]{2}{*}{ FOR_COM } & & $-0,0363 * * *$ & & $-0,0365 * * *$ \\
\hline & & $(0,0012)$ & & $(0,0067)$ \\
\hline \multirow[t]{2}{*}{ FORG_DIR } & & & $-0,0030$ & 0,0153 \\
\hline & & & $(0,4411)$ & $(0,2607)$ \\
\hline \multirow[t]{2}{*}{ SIZE } & $0,0001 * * *$ & $0,0001 * * *$ & $0,0001 * * *$ & $0,0001^{*} * *$ \\
\hline & $(0,0000)$ & $(0,0000)$ & $(0,0000)$ & $(0,0000)$ \\
\hline \multirow[t]{2}{*}{ ROA } & $0,5910 * * *$ & $0,5949 * * *$ & $0,5930 * * *$ & $0,5944 * * *$ \\
\hline & $(0,0000)$ & $(0,0000)$ & $(0,0000)$ & $(0,0000)$ \\
\hline \multirow[t]{2}{*}{ LEV } & $-0,1686 * * *$ & $-0,1657 * * *$ & $-0,1670 * * *$ & $-0,1668^{* * * *}$ \\
\hline & $(0,0000)$ & $(0,0000)$ & $(0,0000)$ & $(0,0000)$ \\
\hline \multirow[t]{2}{*}{ CAPINT } & 0,0260 & 0,0272 & 0,0271 & 0,0265 \\
\hline & $(0,1765)$ & $(0,1656)$ & $(0,1711)$ & $(0,1779)$ \\
\hline Adjusted $\mathrm{R}^{2}$ & 0,4751 & 0,4746 & 0,4744 & 0,4734 \\
\hline F-Statistic & 3,4086 & 3,4042 & 3,4022 & 3,3787 \\
\hline Prob (F-Statistic) & 0,0000 & 0,0000 & 0,0000 & 0,0000 \\
\hline Observation & 911 & 911 & 911 & 911 \\
\hline
\end{tabular}

Keterangan: ADJ_BTD= adjusted total book tax difference; FOR_OWN= proporsi saham asing terhadap total jumlah saham; FOR_COM= proporsi dewan komisaris asing terhadap total dewan komisaris; FORG_DIR= proporsi dewan direksi asing terhadap jumlah keseluruhan dewan; $\mathrm{ROA}=$ rasio laba sebelum pajak pada total aset; SIZE= logaritma natural total aset; $\mathrm{LEV}=$ rasio utang terhadap aset; CAPINT= rasio dari net of property, plant, and equipment pada total aset di periode sebelumnya.

$* * * * * * * ;$ masing-masing signifikan pada $1 \%, 5 \%, 10 \%$ 
regresi non-linear hampir sama dengan model regresi linear baik arah maupun signifikansinya, sebesar $-2,4389$ dan 2,2460 dengan level signifikansi 0,0003 dan 0,0000 $(\alpha<0.01)$. Hal tersebut membentuk keyakinan bahwa koefisien regresi yang dihasilkan tidak dapat diabaikan, sehingga dapat dibuat kesimpulan dari regresi tersebut bahwa kepemilikan asing berpengaruh negatif terhadap penghindaran pajak

Pemeriksaan ketahanan dilakukan untuk menguji ketahanan hasil penelitian terhadap perubahan dalam tipe data yang digunakan dengan cara mengganti variabel dependen dari BTD menjadi adjusted BTD. Cara tersebut dilakukan dengan mengurangi nominal BTD dengan rata-rata BTD pada tiap sektor perusahaan. Selanjutnya, pengujian regresi linear berganda dilakukan dengan model fixed effect. Hasil yang disajikan pada tabel 6 serupa dengan pengujian utama pada tabel 4. Kepemilikan asing dan dewan komisaris asing juga berpengaruh negatif terhadap penghindaran pajak. Kemudian hasil pengujian ini tetap tidak dapat membuktikan bahwa dewan direksi asing berpengaruh pada penghindaran pajak.

\section{SIMPULAN}

Kepemilikan saham oleh asing berpengaruh negatif terhadap praktik penghindaran pajak. Hal ini mengindikasikan bahwa pemilik asing sangat mempertimbangkan cost yang timbul dari praktik penghindaran pajak. Risiko hukum, reputasi perusahaan dan biaya konsultasi perpajakan menjadi penghambat praktik penghindaran pajak. Komisaris asing berpengaruh negatif terhadap praktik penghindaran pajak sehingga dapat dikatakan bahwa komisaris berkewarganegaraan asing taat terhadap peraturan perpajakan di Indonesia. Adanya PMK 19/PMK.03/2018 Tentang Perubahan Kedua atas Peraturan Menteri Keuangan Nomor 70/PMK.03/2017 Tentang Petunjuk Teknis Mengenai Akses Informasi Keuangan untuk Kepentingan Perpajakan merupakan salah satu penyebab komisaris asing menentang praktik penghindaran pajak. Peraturan yang secara khusus ditujukan untuk perusahaan multinasional ini berhasil meminimalisir penghindaran pajak. Keberadaan direktur asing di Indonesia tidak berpengaruh pada penghindaran pajak. Direktur asing sebagai organ yang terlibat langsung pada operasional perusahaan lebih taat pajak. Direktur asing tetap menginginkan long term value dari perusahaan sehingga akan berusaha menerapkan tata kelola perusahaan yang baik dan meminimalisir adanya praktik penghindaran pajak yang bisa memberikan eksposur hukum.

\section{KETERBATASAN DAN SARAN}

Penelitian ini hanya menggunakan satu proksi pengukuran variabel dependen yaitu book tax difference (BTD). Hal ini membuat penelitian tidak memiliki pembanding untuk menguatkan dan melihat konsistensi hasil model regresi. Dalam mendeteksi kepemilikan asing, peneliti hanya mendasarkan pada informasi yang tercatat di perusahaan tersebut. Peneliti belum dapat mendeteksi asal negara yang sebenarnya dapat menjadi pembanding perilaku penghindaran pajak dari negara maju maupun berkembang. Penentuan direktur asing pada penelitian ini masih digeneralisir sehingga belum membedakan jabatan fungsional direktur asing (sebagai direktur utama atau direktur keuangan) yang diduga akan memengaruhi perilaku penghindaran pajaknya.

Penelitian selanjutnya diharapkan dapat menambah proksi pengukuran variabel dependen untuk lebih menguatkan hasil pengujian (robustness test). Misalnya seperti Rusydi dan Martani (2014) yang menggunakan 3 proksi pengukuran penghindaran pajak yaitu dengan ETR, cash ETR, dan BTD. Selain itu, Salihu et al. (2015) juga menggunakan lebih dari 1 pengukuran penghindaran pajak, yaitu accounting ETR, long-term cash ETR, ratio of total tax expense to operating cash flow, dan ratio of tax paid to operating cash flow. Menggolongkan kepemilikan asing berdasarkan asal negara baik dari negara maju maupun negara berkembang untuk mendapatkan hasil yang lebih komprehensif. Membedakan direktur asing sesuai jabatan fungsionalnya (direktur utama dan direktur keuangan) untuk menangkap perbedaan 
perilaku penghindaran pajak.

\section{DAFTAR PUSTAKA}

Alkurdi, A., \& Mardini, G.H. (2020). The impact of ownership structure and the board of directors' composition on tax avoidance strategies: Empirical evidence from Jordan. Journal of Financial Reporting and Accounting, 18(4), 795-812.

Annisa, A., Sari, R, N., \& Ratnawati, V. (2020). Pengaruh Kepemilikan Saham Asing, Kualitas Informasi Internal dan Publisitas Chief Executive Officer Terhadap Penghindaran Pajak. Media Riset Akuntansi dan keuangan, 8(2), 147-158.

Annuar, H.A., Salihu, I.A., \& Obid, S.N.S. (2014). Corporate ownership, governance and tax avoidance: An interactive effects. Procedia-Social and Behavioral Sciences, 164 (August), 150-160.

Arieftiara, D. (2017). Pengaruh kontinjen fit antara strategi bisnis dengan ketidakpastian lingkungan terhadap penghindaran pajak (Disertasi). Universitas Indonesia, Program Studi Ilmu Akuntansi, Depok.

Badan Pusat Statistik. Realisasi investasi penanaman modal dalam negeri, 2017-2019. Diakses dari https:// www.bps.go.id.

Badertscher, B.A., Katz, S.P., \& Rego, S.O. (2013). The separation of ownership and control and corporate tax avoidance. Journal of Accounting and Economics, 56(2-3), 228-250.

Choi, H.M., Sul, W., \& Min, S.K. (2012). Foreign board membership and firm value in Korea. Management Decision, 50(2), 207-233.

Comprix, J., Graham, R.C., \& Moore, J.A. (2011). Empirical evidence on the impact of book-tax differences on divergence of opinion among investors. Journal of the American Taxation Association, 33(1), 51-78.

Dreze, J., \& Stern, N. (1987). Chapter 14: The theory of cost-benefit analysis. Handbook of Public Economics, 2, 909 $-989$.

Gujarati, N., \& Porter, D.C., (2009). Basic Econometrics. New York: McGrawHill/Irwin.

Hanlon, M., \& Slemrod, J. (2009). Evidence for The Possible Information Loss of Confoming Book Income and Taxable Income. Journal of Law and Economics, Vol. 28 No. 2, h. 126- 141
Humas Setkab. (2016). 10 Tahun tidak bayar pajak, Menkeu minta Dirjen Pajak tindak tegas PMA nakal. Diakses dari https://setkab.go.id.

Idzni, I.N., \& Purwanto, A. (2017). Pengaruh ketertarikan investor asing dan kepemilikan institusional terhadap penghindaran pajak perusahaan. Diponegoro Journal of Accounting, 6 (1), 1-12.

Jensen \& Meckling. (1978). Can the survive? Corporation. Financial Analysts Journal, 34(1), 31-37.

Khanna, T., \& Palepu, K. (2000). Is group affiliation profitable in emerging markets? An analysis of diversified Indian business groups. Journal of Finance, 55(2), 867-891.

Kusbandiyah, A., \& Norwani, N.M. (2018). The influence of size firm and ownership structure toward aggressive tax avoidance of manufacture companies listed in Indonesia Stock Exchange. October.

Mardiasmo. (2016). Perpajakan edisi revisi. Yogyakarta: Penerbit Andi.

Muljono, D. (2009). Tax planningmenyiasati pajak dengan bijak. Yogyakarta: Penerbit Andi.

Nadhir, M.G. (2015). Pengaruh minat investor asing terhadap penghindaran pajak perusahaan manufaktur yang terdaftar di BEI 2011-2014. Universitas Indonesia.

Nainggolan, C., \& Sari, D. (2020). Kepentingan asing, aktivitas internasional, dan thin capitalization: Pengaruh terhadap agresivitas pajak di Indonesia. Jurnal Akuntansi dan Bisnis, 19(2), 147.

Peraturan Kementerian Keuangan (PMK) 19/PMK.03/2018 tentang Perubahan Kedua atas Peraturan Menteri Keuangan Nomor 70/PMK.03/2017 Petunjuk Teknis Mengenai Akses Informasi Keuangan untuk Kepentingan Perpajakan. 19 Februari 2018. Lembaran Negara Republik Indonesia Tahun 2018 Nomor 281. Jakarta

Rahayu, N. (2010). Evaluasi atas praktik penghindaran pajak penanaman modal asing. Jurnal Akuntansi dan Keuangan Indonesia, 7(1), 61-78

Rusydi, M.K., \& Martani, D. (2014). Pengaruh struktur kepemilikan terhadap aggressive. Paper dipresentasikan pada acara Simposium Nasional Akuntansi 17, Lombok.

Salihu, I.A., Annuar, H.A., \& Sheikh Obid, S.N. (2015). Foreign investors' interests and corporate tax 
JURNAL AKUNTANSI DAN BISNIS Vol. 21, No. 1, Februari 2021: 29-42

avoidance: Evidence from an emerging economy. Journal of Contemporary Accounting and Economics, 11(2), 138-147.

Shi, A.A., Concepcion, F.R., Laguinday, C.M.R., Ong Hian Huy, T.A.T., \& Unite, A.A. (2020). An analysis of the effects of foreign ownership on the level of tax avoidance across Philippine publicly listed firms. DLSU Business and Economics Review, 30(1), 1-14.

Suandy, E. (2014). Hukum pajak edisi 6. Yogyakarta: Penerbit Salemba Empat.
Suranta, E., Midiastuty, P., \& Hasibuan, H.R. (2020). The effect of foreign ownership structure and foreign commissioners' board of tax avoidance. Journal of Economics, Business, \& Accountancy Ventura, 22 (3), 309-318.

Taylor, G., \& Richardson, G. (2012). International corporate tax avoidance practices: Evidence from Australian firms. International Journal of Accounting, 47(4), 469-496. 